\title{
Genotype $\times$ Environment Interaction for Age at First Calving in Brazilian and Colombian Holsteins
}

\author{
M. F. Cerón-Muñoz, ${ }^{1}$ H. Tonhati, ${ }^{2}$ C. N. Costa, ${ }^{3}$ \\ J. Maldonado-Estrada, ${ }^{4}$ and D. Rojas-Sarmiento ${ }^{5}$ \\ ${ }^{1}$ GRICA-FCA-Universidad de Antioquia, Colombia \\ ${ }^{2}$ FCAV-Universidade Estadual Paulista, Jaboticabal, SP, Brazil \\ ${ }^{3}$ Embrapa Gado de Leite, Juiz de Fora, MG, Brazil \\ ${ }^{4}$ Centauro-FCA-Universidad de Antioquia, Medellín, Colombia \\ ${ }^{5}$ Asociacion Holstein de Colombia
}

genetic progress in milk yield on reproductive performance. Cows having a great genetic potential for milk yield often exhibit reproductive problems, particularly when subjected to climatic stress, especially such as that of (sub)tropical climates (Campos et al., 1994).

Animal fertility is a determining factor in genetic gains of different production systems (Olds et al., 1979; Esslemont and Peeler, 1993). Although heritability estimates for most reproductive traits are usually low, there is sufficient genetic variation to obtain genetic gain by selection of these characteristics (Philipsson, 1981; Thaller and Aumann, 1996), and, as such, it can be effective on long-term production cost reduction (Shook, 1989; Campos et al., 1994).

Oltenacu et al. (1991) reported an antagonistic association between production and conception rate for heifers and cows. However, for AFC, Seykora and McDaniel (1983) stated that selection for milk yield resulted in a favorable reduction in AFC in heifers, in agreement with the reports by McDaniel and El-Sayed (1980), and Hansen et al. (1983a, 1983b). Abubakar et al. (1986) and Pearson de Vaccaro (1974) reported that Holstein cattle were older at first calving in South America than in other countries, and suggested nutritional differences as a main cause.

Animal productive and reproductive potentials are expressed only as much as their environmental conditions allow. The environment does not change the genetic constitution of the individual. However, environmental factors determine the extent to which the phenotype is expressed; therefore, it is possible that the best genotype in one environment may not be in others (Warwick and Legates, 1980). This phenomenon is known as genotype $\times$ environment interaction $(\mathbf{G} \times \mathbf{E})$. Falconer (1952) defined $\mathrm{G} \times \mathrm{E}$ as the change in relative performance of a characteristic expressed in 2 or more genotypes, measured in 2 or more environments. Thus, interactions can involve changes in genotype classification or changes in magnitude of genetic, environmental, and phenotypic variances in differing environments.
Received October 7, 2003.

Accepted February 27, 2004

Corresponding author: M. Cerón-Muñoz; e-mail: mceronm@ universia.net.co. 
Table 1. Number of sires ${ }^{1}$ heifers and average at first calving (AFC) by genetic group of sire in Brazil and Colombia. $^{2}$

\begin{tabular}{|c|c|c|c|c|c|c|c|}
\hline \multicolumn{4}{|c|}{ Brazil } & \multicolumn{4}{|c|}{ Colombia } \\
\hline Genetic group & Sires & Heifers & $\begin{array}{l}\mathrm{AFC} \\
(\mathrm{mo})\end{array}$ & Genetic group & Sires & Heifers & $\begin{array}{l}\mathrm{AFC} \\
(\mathrm{mo})\end{array}$ \\
\hline $\mathrm{Br}(\leq 1979)$ & 334 & 2782 & 30.66 & Co $(\leq 1979)$ & 84 & 1241 & 32.69 \\
\hline Br (1980-1984) & 592 & 5005 & 30.20 & Сo (1980-1984) & 123 & 1935 & 32.80 \\
\hline Br (1985-1993) & 1019 & 3758 & 29.82 & Со (1985-1993) & 142 & 1678 & 31.81 \\
\hline $\mathrm{Ca}(\leq 1976)$ & 100 & 2897 & 29.89 & $\mathrm{Ca}(\leq 1976)$ & 82 & 926 & 31.99 \\
\hline $\mathrm{Ca}(1977-1981)$ & 45 & 3329 & 29.09 & $\mathrm{Ca}(1977-1981)$ & 66 & 2080 & 31.90 \\
\hline $\mathrm{Ca}(1982-1993)$ & 111 & 2522 & 28.56 & $\mathrm{Ca}(1982-1993)$ & 102 & 1734 & 31.85 \\
\hline US $(\leq 1971)$ & 117 & 1688 & 30.37 & US $(\leq 1971)$ & 145 & 796 & 32.38 \\
\hline US (1972-1976) & 204 & 8015 & 29.82 & US (1972-1976) & 318 & 5584 & 32.18 \\
\hline US (1977-1981) & 216 & 12,298 & 29.57 & US (1977-1981) & 315 & 4946 & 32.04 \\
\hline US (1982-1993) & 281 & 8945 & 28.37 & US (1982-1993) & 364 & 4649 & 31.69 \\
\hline Total & 3019 & 51,239 & & & 1741 & 25,569 & \\
\hline
\end{tabular}

${ }^{1} 530$ sires commons in the 2 countries.

${ }^{2} \mathrm{Br}=$ Brazilian sires; $\mathrm{Ca}=$ Canadian sires Co $=$ Colombian sires; US = American sires.

Comparative reproductive characteristics and $\mathrm{G} \times \mathrm{E}$ studies in cattle populations located in different regions or countries are needed to determine whether imported genotypes exhibit reproductive problems in (sub)tropical countries. For Lytton and Legates (1966), G×E can be observed in reproductive characteristics and such variables could be weighted along with production traits in animal selection programs. The objective of this study was to determine the genotype $\times$ environment interaction of age at first calving of Holstein cattle between Brazil and Colombia.

\section{MATERIALS AND METHODS}

Data from 76,808 first calvings of Holstein cows from 7 regions in Brazil and 5 regions in Colombia were obtained for Holstein cows calving from 1980 through 1997. Data were from the Brazilian Association of Holstein Cattle Ranchers, available from the National Animal Sciences Database, from EMBRAPA Gado de Leite, Juiz de Fora, MG, Brazil, and from the Colombian Holstein Association (Table 1). Contemporary groups were made up by herd-year, and groups with fewer than 5 cows were discarded. For the analysis there were considered 6742 and 3219 herd-year from 1287 and 374 herds in Brazil and Colombia, respectively. In addition, sires were excluded if they did not have at least 2 daughters in each 1 of 2 herds from Brazil and Colombia. Genetic groups of sires were made by considering origin of sire (Brazil, Canada, Colombia, and United States) and dates of birth within each origin, as described in Table 1. Also, cows were grouped by genetic background according to the classification of the Holstein associations in each country. Only purebred Holsteins and cows with $\geq 31 / 32$ Holstein genetics were included.
Bivariate analysis was done with an animal model, using the derivative-free restricted maximum likelihood method. The (co)variance components were estimated with the MTDFREML (Boldman et al., 1993) program. The fixed effects of contemporary group, the genetic group of the sire, and the genetic group of the cow, as well as the random effects of animal and residual, were included. The model of bi-trait analysis for the AFC between the 2 countries can be represented in a matrix notation as:

$$
\mathrm{y}_{\mathrm{i}}=\mathrm{X}_{\mathrm{i}} \mathrm{b}_{\mathrm{i}}+\mathrm{Z}_{\mathrm{i}} \mathrm{a}_{\mathrm{i}}+\mathrm{e}_{\mathrm{i}}
$$

with

$$
\mathrm{y}=\left[\begin{array}{l}
\mathrm{y}_{1} \\
\mathrm{y}_{2}
\end{array}\right]=\left[\begin{array}{cc}
\mathrm{X}_{1} & 0 \\
0 & \mathrm{X}_{2}
\end{array}\right]\left[\begin{array}{l}
\mathrm{b}_{1} \\
\mathrm{~b}_{2}
\end{array}\right]+\left[\begin{array}{cc}
\mathrm{Z}_{1} & 0 \\
0 & \mathrm{Z}_{2}
\end{array}\right]\left[\begin{array}{l}
\mathrm{a}_{1} \\
\mathrm{a}_{2}
\end{array}\right]+\left[\begin{array}{l}
\mathrm{e}_{1} \\
\mathrm{e}_{2}
\end{array}\right]
$$

where:

Vector of observations for the ith age at first calving, $\mathrm{i}=1=$ Brazil, and $2=$ Colombia

Vector of fixed effects of herd year, cow genetic group and sire genetic group for the ith characteristic;

Vector of random additive genetic effect of animal for the $i^{\text {th }}$ characteristic;

Vector of random residual effect for the $i^{\text {th }}$ characteristic. $X_{i}$ is the incidence matrix related to the fixed effects $b_{i}$, and $Z_{i}$ is the incidence matrix related to the random additive genetic effect of animal $\left(a_{i}\right)$.

The assumptions in relation to 1 st and 2 nd moments were:

$$
\left[\begin{array}{l}
a \\
e
\end{array}\right] \sim N M V\left(\left[\begin{array}{l}
0 \\
0
\end{array}\right],\left[\begin{array}{ll}
G & 0 \\
0 & R
\end{array}\right]\right)
$$


Table 2. Estimates of (co)variance, heritabilities, and genetic correlations of age at first calving of Brazilian and Colombian Holstein cattle.

\begin{tabular}{lrr}
\hline & Brazil & Colombia \\
\hline Average age of the cows at first calving (months) & 29.50 & 32.07 \\
Standard deviation & 3.97 & 3.50 \\
Coefficient of variation $(\%)$ & 13.46 & 10.93 \\
Additive genetic variance $\left(\mathrm{mo}^{2}\right)$ & 2.21 & 1.02 \\
Residual variance $\left(\mathrm{mo}^{2}\right)$ & 9.41 & 6.84 \\
Heritability & 0.19 & 0.13 \\
Genetic covariance between Brazil and Colombia & \multicolumn{2}{c}{ Brazil-Colombia } \\
Genetic correlation between Brazil and Colombia & \multicolumn{2}{c}{0.17} \\
\hline
\end{tabular}

where:

$\mathrm{G}=\mathrm{A} \otimes \mathrm{G}_{0}$ is the (co) variance additive genetic matrix for the characteristics and

$$
G_{0}=\left[\begin{array}{cc}
\sigma_{a_{11}}^{2} & \sigma_{a_{12}} \\
\sigma_{a_{21}} & \sigma_{a_{22}}^{2}
\end{array}\right]
$$

$\sigma_{a_{\mathrm{ii}}}^{2}$ is the additive genetic variance of characteristic $\mathrm{i}=1,2$, and $\sigma_{a_{12}}^{2}$ is the additive genetic covariance between characteristics 1 and 2 ;

$A$ is the relationship matrix and $\otimes$ is the direct product; and

$\mathrm{R}=\mathrm{I} \otimes \mathrm{R}_{0}$ is the residual (co)variance matrix between the characteristics, and

$$
R_{0}=\left[\begin{array}{cc}
\sigma_{e_{11}}^{2} & 0 \\
0 & \sigma_{e_{22}}^{2}
\end{array}\right]
$$

$\sigma_{e_{\mathrm{ii}}}^{2}$ is the residual variance for characteristic $\mathrm{i}=1,2$.

\section{RESULTS AND DISCUSSION}

The average AFC were $29.5 \pm 4.0$ and $32.1 \pm 3.5$ mo for Brazil and Colombia, respectively (Table 2). The difference in average AFC between countries reflects the different reproductive performance of heifers. It is likely that weather and management conditions particular to each country are determinant in their reproductive performance. These values are similar to those found in other Latin American countries. In a literature review by Pearson de Vaccaro (1974), the AFC among Holstein-Friesian in South American countries varied from 30 to 36 mo. Because AFC for Holstein dairy herds in Brazil and Colombia are at the lower end of that range in the current report, there appears to have been some improvement from the earlier data.

The components of additive genetic and residual variances and the heritability coefficient were $2.21 \mathrm{mo}^{2}$,
$9.41 \mathrm{mo}^{2}$, and 0.19 , respectively for Brazil, and 1.02 $\mathrm{mo}^{2}, 6.84 \mathrm{mo}^{2}$, and 0.13 , respectively, for Colombia. Heritability values were similar to the 0.26 estimated by Shanks et al. (1981) and 0.16 estimated by Hansen et al. (1983b), but greater than that of $0.05 \pm 0.03$ estimated by Seykora and McDaniel (1983). In contrast, Abubakar et al. (1986) found an abnormal heritability value of 2.19 for AFC in Colombian Holstein cattle.

The genetic correlation of AFC between Brazil and Colombia was 0.78 , suggesting that $\mathrm{G} \times \mathrm{E}$ would have an important impact on animal performance (Robertson, 1959). It also highlights that progeny of North American sires had different performance in these 2 countries, leading to changes in the rank of the sires as a consequence of this interaction. Apparently, expression of genes responsible for age at first calving varies across environments.

In conclusion, we suggest that care should be taken in considering sires when comparing progeny in different dairy production systems in the tropics because of the possibility of $\mathrm{G} \times \mathrm{E}$ for relative rankings.

\section{ACKNOWLEDGMENTS}

Financial support from the Fundacao de Amparo a Pesquisa do Estado de Sao Paulo, Brazil.

\section{REFERENCES}

Abubakar, B. Y., R. E. McDowell, and L. D. Van Vleck. 1986. Genetic evaluation of Holsteins in Colombia. J. Dairy Sci. 69:1081-1086.

Boldman, K. G., L. A. Kriese, and L. D. Van Vleck. 1993. A manual for the use of MTDFREML: A set of programs of variances and co variances (DRAFT). Department of Agriculture/Agricultural Research Service, Lincoln, NE.

Campos, M. S., C. J. Wilcox, C. M. Becerril, and A. Diz. 1994. Genetic parameters for yield and reproductive traits of Holstein and Jersey cattle in Florida. J. Dairy Sci. 77:867-873.

Esslemont, R. J., and E. J. Peeler. 1993. The scope for raising margins in dairy herds by improving fertility and health British Vet. J. 14:537-547.

Falconer, D. 1952. The problem of environment and selection. Am. Nat. 86:293-298.

Hansen, L. B., A. E. Freeman, and P. J. Berger. 1983a. Association of heifer with cow fertility and yield in dairy cattle. J. Dairy Sci. 66:306-314. 
Hansen, L. B., A. E. Freeman, and P. J. Berger. 1983b. Yield and fertility relationships in dairy cattle. J. Dairy Sci. 66:293-305.

Lytton, V. H., and J. E. Legates. 1966. Sire by region interaction for production traits in dairy cattle. J. Dairy Sci. 49:874-878.

McDaniel, B. T., and M. El-Sayed. 1980. Association among genetic values, heart girths, reproductive measures and milk yields. J. Dairy Sci. 63:(Suppl. 1):93. (Abstr.)

Olds, D., T. Cooper, and F. A. Thrift. 1979. Effect of days open on economic aspects of current lactation. J. Dairy Sci. 62:1167-1170.

Oltenacu, P. A., A. Frick, and B. Lindhé. 1991. Relationship of fertility to milk yield in Swedish cattle. J. Dairy Sci. 74:264-268.

Pearson de Vaccaro, L. 1974. Dairy cattle breeding in South America. World. Anim. Rev. FAO, Rome, Italy http://www.fao.org/DOCREP/004/X6500E/X6500E00.htm\# (Accessed February 27, 2004).

Philipsson, J. 1981. Genetic aspects of female fertility in dairy cattle. Livest. Prod. Sci. 8:307-319.
Robertson, A. 1959. The sampling variance of the genetic correlation coefficient. Biometrics 15:469-485.

Seykora, A. J., and B. T. McDaniel. 1983. Heritabilities and correlations of lactation yields and fertility for Holsteins. J. Dairy Sci. 66:1486-1493.

Shanks, R. D., P. J. Berger, A. E. Freeman, and F. N. Dickinson. 1982. Genetic and phenotypic relations of milk production and postpartum length with health and lactation curve traits by lactation. J. Dairy Sci. 65:1612-1623.

Shook, G. E. 1989. Selection for disease resistance. J. Dairy Sci. 72:1349-1362.

Thaller, G., and J. Aumann. 1996. Genetic evaluation of male and female fertility. Pages 21-23 in International Workshop of Genetic Improvement of Functional Traits in Cattle, Faculte Univ. des Science Agronomique, Gembloux, Belgium.

Warwick, E. J., and J. E. Legates. 1980. Cria y mejora del ganado. 3rd ed. McGraw-Hill, México City, México. 